\title{
STATE RESPONSIBILITY FOR CLIMATE CHANGE DAMAGES
}

\author{
Maciej Nyka*
}

\begin{abstract}
The state's liability for damages in the field of climate change remains one of those areas of international law that has not yet been comprehensively regulated. At present, the Warsaw International Mechanism for Loss and Damage, specific to the norms of international climate law, is not an alternative to the general principles of international law regulating responsibility and compensation issues of the states in the sphere of international climate law. The application of customary international legal mechanisms of responsibility of states in relation to climate damage can be a kind of challenge. Both the damage itself and elements such as causation or the possibility of attributing responsibility to the state pose a significant challenge in the sphere of climate protection. On the other hand, it is impossible not to notice that properly applied norms of general international law make it possible to overcome the difficulties arising from the specificity of the responsibility of countries for climate change. The latest jurisprudence of the International Court of Justice in environmental matters creates a framework for the settlement and implementation of possible liability for damages in the area of climate change.
\end{abstract}

Keywords: climate change, climate liability, state responsibility, climate change damages

* Dr. habil. Maciej Nyka, Associate Professor, Faculty of Law and Administration, University of Gdansk; correspondence address: ul. Bażyńskiego 6, 80-980 Gdańsk, Poland; e-mail: maciej.nyka@ug.edu.pl; https://orcid.org/0000-0003-0786-7785. 


\section{INTRODUCTION}

The responsibility of states in the field of environmental protection poses a significant challenge. Although the issue has been present from the very beginning of the formation of international environmental law, it still has not been comprehensively regulated. The need to determine the principles of state responsibility in the area of climate change seems particularly urgent. This is because they are described as the most substantial damage caused by human beings to other human beings in the entire history of our species ${ }^{1}$. This may be surprising, especially when the issue of climate change is becoming one of the leading concerns of both domestic and international law ${ }^{2}$. In the context of responsibility for climate change, the focus is on the obligations of highly developed countries, to developing countries, which not infrequently bear a disproportionate share of the damages and risks associated with climate change relative to their contribution to the greenhouse effect ${ }^{3}$. In this context, it is necessary to analyze the applicability of the general principles of international legal liability of states for environmental damage to climate change-related damage, as well as the effectiveness of specific liability regimes in this area that are evolving under the new emerging field of international environmental law - climate protection law ${ }^{4}$.

1 Janina Ciechanowicz-McLean, "Prawno-ekonomiczne aspekty zmian klimatu," in Zmiany klimatu a spoteczeństwo, eds. Leszek Karski and Irena Grochowska (Warsaw: C.H. Beck, 2010), 341.

2 David A. King, "Climate Change Science: Adapt, Mitigate or Ignore?," Science 303, no. 5655 (2004): 176.

3 Jutta Brunnée and Stephen J. Toope, "Climate Change: Building a global legal regime," in Legitimacy and Legality in International Law. An International account, ed. Jutta Brunnée and Stephen Toope (Cambridge: Cambridge University Press, 2010), 128.

4 Janina Ciechanowicz-McLean, Prawo ochrony klimatu (Warsaw: Powszechne Wydawnictwo Prawnicze, 2016), 11-12. 


\section{RESPONSIBILITY OF SUBJECTS OF INTERNATIONAL LAW FOR ENVIRONMENTAL DAMAGE - PRELIMINARY ISSUES}

The responsibility of subjects of international law is an area of international law that has not yet been codified ${ }^{5}$. It does not mean, however, that this very important problem of international relations does not exist in international law. It is quite the contrary, as evidenced by numerous analyses of the doctrine as well as a large number of decisions of international courts, which in the field of international legal responsibility of states were able to identify in this area the norms of customary law and successfully apply them ${ }^{6}$. The International Law Commission distinguishes between ${ }^{7}$ responsibility for torts under international law and liability for acts not prohibited by international law. In the traditional view, the responsibility of states is connected with a situation, in which as a result of committing an illegal act (as a result of violation of an international obligation by the state) a new legal relationship is created ${ }^{8}$, whose content is regulated by secondary norms regulating the consequences of state action that is not in line with legal norms ${ }^{9}$. International legal liability for acts not prohibited by international law is exercised entirely on the basis of primary legislation. It becomes important in this context to analyze the liability of states for non-prohibited acts in the context of obligations having a treaty basis or arising from international custom. The key role in respect of responsibility for transboundary environmental damage, including climate damage, will be played here by the obligation to ensure that actions taken by the state within its jurisdiction and control will not adversely affect other states and territories beyond state jurisdiction. The distinction drawn above between

5 Władysław Czapliński, Podstawowe zagadnienia prawa międzynarodowego. Zarys wyktadu (Warsaw: Wydawnictwo Uniwersytetu Warszawskiego, 2009), 155; see also Ciechanowicz-McLean, Prawo ochrony klimatu, 153.

6 Ewa Czech, Szkoda w obszarze środowiska i wina, jako determinanty odpowiedzialności administracyjnej za szkodę (Białystok: Trans Humana, 2008), 33.

7 Ciechanowicz-McLean, Prawo ochrony klimatu, 153.

8 Anna Zbaraszewska, "Prawnomiędzynarodowa odpowiedzialność za szkody transgraniczne w środowisku - problem prewencji," Ruch Prawniczy, Ekonomiczny i Socjologiczny 70 , no. 2 (2008): 117.

9 Zbaraszewska, "Prawnomiędzynarodowa odpowiedzialność za szkody," 117. 
responsibility for torts under international law and liability for acts not prohibited by international law seems in practice to be of lesser importance than is attributed to it by the International Law Commission and part of the doctrine. For example, former President of the International Court of Justice Rosalyn Higgins states that a tort of international law may be the mere fact of allowing damage to occur ${ }^{10}$.

The obligation to make reparation for damage resulting from a violation of the norms of international law is considered as one of the fundamental principles of this law. In the classic formula adopted by the Permanent Court of International Justice, it means the obligation to restore the state before the damage occurred ${ }^{11}$. Being an attempt at a comprehensive formulation of the principles of state responsibility in international law, the Articles on the liability of states for acts contrary to international law, constituting a non-binding proposal of the International Law Commission, in Article 31 par. 1 speak about the need to fully repair the damage. The damage itself is understood broadly and takes into account both material and non-material dimensions ${ }^{12}$. A similarly broad interpretation has been adopted by the International Law Commission with respect to the concept of reparation, which can encompass restitution as well as compensation, rehabilitation and even guarantees of non-repetition of violations ${ }^{13}$.

With respect to environmental damage, the principles of legal international responsibility of states appear to serve two basic functions. First, they reinforce first-level norms derived from numerous international treaties and custom in the area of environmental protection and environmental damage prevention. Second, they enable states to pursue claims arising out of violations of international law norms in the area of environmental pro-

10 Rosalyn Higgins, Problems and Process: International Law and How We Use It, $2^{\text {nd }}$ ed. (Oxford: Clarendon Press, 2003), 165; see also Christina Voigt, "State Responsibility for Climate Change Damages," Nordic Journal of International Law 77 (2008): 8.

11 Permanent Court of International Justice Ruling Factory at Chorzow (Germ. v. Pol.), 1928 P.C.I.J. (ser. A) No. 17 (Sept. 13).

12 International Law Commission, Draft Articles on Responsibility of States for Internationally Wrongful Acts, November 2001, Supplement No. 10 (A/56/10), chp.IV.E.1, https://www.refworld.org/docid/3ddb8f804.html, accessed January 31, 2021.

${ }_{13}$ International Law Commission, Draft Articles on Responsibility of States for Internationally Wrongful Acts, art. 34. 
tection ${ }^{14}$. The effectiveness of the implementation of these two functions, which is assessed quite critically in the doctrine, remains an open question $^{15}$. The disaster at the Chernobyl nuclear power plant is an example cited in the literature. Despite the obvious damage resulting from the lack of precautionary rules at the plant, the states that suffered in the disaster did not file claims against the USSR. The reason for this was both political (the states that suffered the most were those that were politically dependent on the Soviet Union) and legal doubts about the practical feasibility of such claims ${ }^{16}$. It is worth noting, however, that nowadays it is unlikely that a disaster of this scale will not be responded to by the affected states. Precedents are already appearing. Although the plaintiffs are individuals, the claims are based on public international legal norms. This justifies the high likelihood of damage claims in the specific area of climate law.

\section{SPECIFIC BASES FOR STATES' RESPONSIBILITY FOR CLIMATE DAMAGE}

In addition to the norms of customary law codified in the work of the International Law Commission, the norms of States' compensatory liability for damages resulting from climate change can also be identified within the specific regime of international climate law. If the norms regulating the exercise of States' compensatory liability for damages resulting from climate change function within its framework, norms of this type would exclude or limit the possibility of applying the general principles of States' compensatory liability ${ }^{17}$. However, it would be relatively difficult to derive the theses from the norms of international climate law that they

14 Voigt, "State Responsibility," 3.

15 Francisco Orrego Vicun, "Institut de Droit International - Resolution on Responsibility and Liability: Responsibility and liability for Environmental Damage under International Law: Issues and Trends," Georgetown International Environmental Law Review 10 (1998): 279.

16 Voigt, "State Responsibility," 3.

17 Bruno Simma and Dirk Pulkowski, "Of Planets and the Universe: Self Contained Regimes in International Law,” European Journal of International Law 17, no. 3 (2006): 529. 
constitute an example of a classic self-contained regimes ${ }^{18}$, nevertheless, certain elements related to the implementation of state responsibility may find their source in these norms. Opinions appear in the doctrine that the United Nations Framework Convention on Climate Change, along with other treaties relating to climate protection and decisions of the Conference of the States Parties, is sufficiently operative to exclude the application of liability instruments based on custom, in particular the principle prohibiting the use of the territory of the state in a way that would generate negative cross-border impacts ${ }^{19}$. However, such opinions do not seem to be sufficiently justified at present.

In the context of the specific grounds for the implementation of international legal responsibility in climate protection, a special role is played by the Paris Agreement ${ }^{20}$, and especially the Warsaw International Mechanism for Loss and Damage contained therein, which was adopted during the Conference of the States Parties to the Convention in Warsaw (COP19). In accordance with the assumptions of the Bali Action Plan adopted in 2007, efforts have been made to create a mechanism to ensure full, effective and sustainable implementation of the Convention ${ }^{21}$. This mechanism was intended as a response by developed countries to the challenges faced by developing countries in the area of climate change adaptation, and as a political cost of engaging developing countries in climate change mitigation processes ${ }^{22}$. The shape of this instrument of international climate law was determined at the Conference of the States Parties to the Convention in Lima in 2014 (COP20).

The arrangements for the Warsaw International Mechanism for Loss and Damage were introduced into the Paris Agreement adopted in 2015 in

18 Małgosia Fitzmaurice and Catherine Redgwell, "Environmental Non-Compliance Procedures and International Law," Netherlands Yearbook of International Law 31 (2000): 35.

19 Alexander Zahar, "Methological issues in climate law," Climate Law 5, no. 1 (2015): $25-34$.

20 Paris Agreement to the United Nations Framework Convention on Climate Change FCCC/CP/2015/10/Add.1.

21 Decision 1/CP.13 par. 1.

22 Decision 1/CP.13 par 1b i 1c, see Benoit Mayer, "Climate Change Reparations and the Law and Practice on State Responsibility," Asian Journal of International Law 7 (2017): 195. 
Article 8. The introduction of the Warsaw International Mechanism for Loss and Damage into the Paris Agreement is undoubtedly a success for developing countries, whose scope of responsibilities with respect to mitigation actions in the Paris Agreement has been significantly expanded ${ }^{23}$.

The conditions for the application of the Warsaw Mechanism in the context of the effects of COP21, within the framework of which the Paris Agreement was adopted, result firstly from the Agreement itself, but also, and it is worth mentioning, from Decision 1/CP.21 concerning the adoption of that Agreement, which constitutes an extremely important tool for interpreting that Agreement ${ }^{24}$. Article 8 of the Paris Agreement emphasizes the role and importance of preventing, reducing and remedying loss and damage associated with the adverse effects of climate change, associated extreme meteorological events, slow-onset events. It also emphasizes the roles of sustainable development in preventing and reducing losses $^{25}$. It identifies areas for collaboration, broadening understanding, action, and support, and provides a framework for working with experts ${ }^{26}$. On the other hand, however, with all due resoluteness, but also with some disappointment in the context of the objectives declared during the preparatory work on the functioning of the Mechanism, on the grounds of Article 8 of the Agreement, it does not, at this stage of its implementation and development, create any binding obligations in terms of liability for damages ${ }^{27}$. The reservation concerning the current stage of implementation of the mechanism mentioned in article 8 of the Agreement is important insofar as paragraphs 2 and 3 of article 8 of the Agreement provide a legal basis for work on the strengthening and development of the mechanism,

23 Maciej Nyka, "Trade related instruments of promotion of human right to the environment in international climate law," in Právo na životné prostredie a nastroje jeho presadzovania, ed. Soňa Košičiarová (Trnava: Trnavská univerzita. Právnická fakulta, 2016), 176.

24 Mary Jane Mace and Roda Verheyen "Loss, Damage and Responsibility after COP21: All Options Open for the Paris Agreement," Review of European Community \& International Environmental Law 25, no. 2 (2016): 204.

25 Paris Agreement to the United Nations Framework Convention on Climate Change art. 8 (1).

26 Paris Agreement to the United Nations Framework Convention on Climate Change art. 8 (4-5).

27 Decision 1/CP.21, par. 51. 
also in the direction of the possible creation of conditions for the realization of compensation liability on the basis of this norm.

In the context of Decision 1/CP.21 on the adoption of the Paris Agreement, paragraphs 47-51 play an important role in the context of the Warsaw Mechanism. Here, too, we find provisions on the continuation of work on the development of a compensation mechanism within the specific regime of international climate protection law. Its purpose is to create an organizational structure and procedures for the efficient management of climate-related risks. On the other hand, also in the case of this document, it is impossible to find elements that would suggest the possibility of implementing liability for damages on the basis of its content and the Paris Agreement. The Warsaw Mechanism must be treated rather as serving the promotion of good practices, or creating recommendations, than creating conditions for the realisation of compensation claims ${ }^{28}$. This issue was resolved in point 51 stating that Art. 8 of the Agreement is not related and does not create a basis for liability and compensation.

As stated above, the norms of international climate law do not provide grounds for claims for compensation for damages caused by the effects of climate change. Perhaps as part of the evolution of the system based on the Paris Agreement, the Warsaw International Mechanism for Loss and Damage it will gain such an opportunity. Its evolution is inscribed both in the spirit and in the text of this agreement. And in the face of more and more evident damage resulting from climate change, the development of this mechanism towards the creation of a specific mechanism for pursuing compensation claims in relations between countries seems to be a logical direction. The above assumption is also justified because the creation of an alternative to the liability mechanisms of states based on general principles would, on the one hand, increase the effectiveness of the possibility of realizing such claims, and, on the other hand, would also allow their quantitative, generic or subjective limitation. This is a key issue if we take into account the potential scale of damages and claims.

28 Florentina Similinger and Benoit Mayer, "Legal Responses to Climate Change Induced Loss and Damage," in Loss and Damage from Climate Change Concepts, Methods and Policy Options, eds. Reinchard Mechler, Laurens M. Bouwer, Thomas Schinko, Swenja Surminski, and JoAnne Linnerooth-Bayer (Cham: SpringerOpen, 2019), 196. 


\section{STATE LIABILITY FOR CLIMATE DAMAGE CARRIED OUT ON GENERAL PRINCIPLES}

The impossibility of exercising states' liability for damages in the area of climate change under the specific mechanisms of international climate law by no means precludes the pursuit of such claims. They can be pursued under traditional mechanisms that have been known to international law for years. And while international courts and tribunals have not yet adjudicated climate claims arising in state-to-state relations, it would be wrong to claim that they are not adequately equipped to do so, or that there is no legal or factual basis for such disputes to arise. In fact, courts and tribunals have resolved interstate disputes in the area of international environmental law, and also have a track record in the area of compensation claims.

The articles on the responsibility of states for acts contrary to international law prepared by the International Law Commission in Article 2 provide for two conditions for the recognition of state action as contrary to international law, which will give rise to state responsibility. The first essential condition is the imputability of the act or the omission to the state. In the context of liability for climate damage, the implementation of this condition may give rise to certain practical difficulties. It must be remembered that climate change is the result of the sum of actions taken by all jurisdictions accumulating over the decades basically since the industrial revolution. Moreover, anthropogenic emissions coexist with emissions resulting from natural processes, and their separation is possible only conventionally and imprecisely. It should also be remembered that anthropogenic emissions for the most part do not result from the activities of states per se, but from entities operating on their territory. On the other hand, international legal liability, including liability in the area of environmental protection or climate law, may arise both as a result of actions taken by the state and as a result of omissions ${ }^{29}$. The obligation of due diligence requires the state to counteract, control the activities carried out on its territory and also, in international legal terms, to assume some responsibility for cross-border impacts resulting from the activities of private

29 Maria Magdalena Kenig-Witkowska, Międzynarodowe prawo środowiska. Wybrane zagadnienia systemowe (Warsaw: WoltersKluwer, 2011), 140. 
entities located on the territory of the state ${ }^{30}$. Obligations of a procedural nature incumbent on the state to implement the principle of prevention were identified by the International Court of Justice in the Pulp Mills case $^{31}$. The possibility of attributing liability to the state for environmental damage caused by private entities operating within its territory precisely in the event of a breach of good governance standards was identified by International Court of Justice Judge Shahabuddeen in his dissenting opinion in Nauru vs. Australia ${ }^{32}$.

The International Law Commission, in its 2001 articles on the prevention of transboundary damages, identifies the conditions under which state action can be considered to manifest due diligence. The ILC's Special Rapporteur, P.S. Rao, in his second and third reports, identifies the definitional elements of due diligence, i.e.: (1) a State should have a legal system and material means sufficient to guarantee the fulfilment of its international obligations; (2) a State should establish and maintain an adequate administrative apparatus to enable it to fulfil these obligations; (3) the degree of due diligence required may vary according to the degree of development and technical awareness of individual States; (4) industrialized and technologically advanced States may be expected to take more far-reaching preventive measures; 5) each State, irrespective of its level of development, must monitor the risky activities carried out in its territory; 6) the degree of diligence required must be proportionate to the degree of risk involved in the type of hazardous activity in question; 7) the damage must be foreseeable; 8) the State must know or ought to have known that activities entailing the risk of significant transboundary damage are being carried out in its territory; 9) the greater the degree of unacceptable damage, the greater the diligence required to prevent transboundary damage must be ${ }^{33}$.

30 James Crawford and Simon Olleson, "The Nature and Forms of International Responsibility," in International Law, eds. Malcolm D. Evans (New York: Oxford University Press, 2003), 79.

31 Pulp Mills on the River Uruguay (Argentina v. Uruguay), Judgment, I.C.J. Reports 2010, p. 14.

32 Certain Phosphate Lands in Nauru, (Nauru v Australia), Preliminary Objections, Judgment, I.C.J. Reports 1992 p. 240.

33 Zbaraszewska, "Prawnomiędzynarodowa odpowiedzialność za szkody," 121-122. 
The second condition identified by custom and reaffirmed in article 2 of the Articles on Responsibility of States is the possibility of a breach of an international legal obligation. This obligation may arise from the norms of customary law, but also, it should be emphasized, the norms of international climate law increasingly often contain precise obligations, which seem to be able to provide a substantive legal basis for compensation claims. Relatively often, when resolving disputes in the area of environmental protection, the prohibition arising from international custom to conduct activities whose negative effects will affect the territory of another state, or areas beyond the jurisdiction of states, is used as a substantive legal basis. This restriction, which implements the Latin maxim sic utere tuo, ut alienum non laedas, is much more rooted in the civil law tradition ${ }^{34}$, than international environmental law, where it has been identified for a relatively short time ${ }^{35}$. This principle of customary law is nowadays reflected in a number of acts of international law ${ }^{36}$, e.g. the Stockholm Declaration ${ }^{37}$, Rio de Janeiro Declaration ${ }^{38}$, or directly in acts of international climate law - the United Nations Framework Convention on Climate Change ${ }^{39}$. Two primary obligations under the principle of refraining from engaging in activities that have a negative transboundary impact are identified. The first concerns the obligation of states to prevent, reduce and control pollution and environmental damage. The second refers to the obligation to cooperate internationally in the area of reducing environmental risks by notifying hazards, negotiating and, where appropriate, carrying out environmental impact assessment procedures $^{40}$.

34 Ciechanowicz-McLean, Prawo ochrony klimatu, 153; Kenig-Witkowska, Międzynarodowe prawo środowiska, 139.

35 Patricia Birnie and Alan Boyle, International Law \& the Environment, 2nd ed. (Oxford: Oxford University Press, 2002), 104.

36 see Kazimierz Kocot, Prawnomiędzynarodowe zasady sozologii (Warsaw-Wrocław: Polskie Wydawnictwa Naukowe, 1977); Janina Ciechanowicz-McLean and Maciej Nyka, Environmental Law (Gdańsk, Warsaw: Wolters Kluwer, 2016), 114; Kenig-Witkowska, Międzynarodowe prawo środowiska, 139.

37 Principle 21.

38 Principle 2.

39 United Nations Framework Convention on Climate Change A/RES/48/189.

40 Ciechanowicz-McLean and Nyka, Environmental Law, 116. 
The jurisprudence of the principle of avoiding negative transboundary impacts was first formulated in 1941 in the famous case of Trail Smelter, in a dispute between the United States and Canada. Analyzing the obligations of states in the field of preventing transboundary emissions, the Arbitration Tribunal stated that states have no right to use their territory or allow it to be used in a way that would cause property or personal damage, if these impacts are serious and the existence of the damage is confirmed with clear and convincing evidence ${ }^{41}$. This principle, and the conditions for implementation of states' responsibilities arising from the Trail Smelter case, were subsequently reaffirmed in the Corfu Channel $\mathrm{Case}^{42}$. Here, the International Court of Justice held that it is the duty of every state not to allow its territory to be used in a way that conflicts with the powers of other states ${ }^{43}$. In the context of environmental protection, in its Advisory Opinion on the Legality of the Use of Nuclear Weapons, the International Court of Justice stated that the environment is not an abstract concept, but constitutes a living space and determines the quality of life and health of human beings, including future generations. The general obligation to ensure that actions taken by states within their jurisdiction and control respect the environment of other states and areas beyond the limits of state jurisdiction is now part of the body of international environmental law ${ }^{44}$. In a similar vein, this reflection was repeated in the Gabcikovo-Nagymaros case where the International Court of Justice held that the duty to prevent transboundary environmental damage as formulated in the Trail Smelter judgment is now part of international environmental law ${ }^{45}$.

41 Trail Smelter (United States, Canada), 3 UNRIAA, p. 1905, 1952.

42 Corfu Channel, United Kingdom v Albania, Judgment, Merits, [1949] ICJ Rep 4.

43 Corfu Channel, United Kingdom v Albania, Judgment, Merits, [1949] ICJ Rep 4.

44 Legality of the Threat or Use of Nuclear Weapons, Advisory Opinion, I.C.J. Reports 1996, p. 226 par 29.

45 Gabčikovo-Nagymaros Project, Hungary v Slovakia, Judgment, Merits, [1997] ICJ Rep 7. 


\section{THE LEGAL AND MATERIAL BASES FOR THE IMPLEMENTATION OF THE RESPONSIBILITY OF STATES IN THE FIELD \\ OF ENVIRONMENTAL PROTECTION}

The fact that, at the present stage of its development, there are no procedural or institutional foundations for the realization of the compensation liability of states within the framework of the Warsaw Mechanism, does not make the norms of international climate law incapable of finding within their framework material-legal grounds for compensation claims. Although the violation of the principle of refraining from transboundary impacts results from the norms of customary international law, alternative obligations on the basis of which it is possible to establish the existence of an obligation to protect the climate by the state appear, for example, in the United Nations Framework Convention on Climate Change or in the Paris Agreement. As a consequence of their violation, it becomes possible to initiate second-degree norms resulting from international custom concerning the implementation of liability.

In the context of the above-mentioned considerations regarding the exercise of due diligence by the state, it is worth pointing to the possibility that states violate Article 2 of the Convention, which provides for taking preventive measures related to the stabilization of emission levels in order to limit climate change ${ }^{46}$. The literature also points to Article 4(2)(a) of the Framework Convention on Climate Change as the source of obligations of highly developed countries to take action in the area of climate change ${ }^{47}$. Similarly, the Paris Agreement may constitute a source of responsibility of the states parties, for example, in the area of implementation of ambitious actions declared by the states in order to achieve the goal of the convention listed in article 2 . These obligations may concern the state's contribution to the reduction of $\mathrm{CO} 2$ emissions (article 4), or the implementation of adaptation goals (article 7).

46 Voigt, "State Responsibility," 5.

47 Voigt, "State Responsibility," 6. 


\section{CLIMATE DAMAGE AS A SPECIFIC TYPE OF ENVIRONMENTAL DAMAGE}

International environmental law has not developed a single, common and consistent definition of the environment ${ }^{48}$. This is due to the presence of fragmentation in international law, which can also be observed in the specific area of international environmental law $^{49}$, and sectoriality of international environmental law regulations. This is a significant disadvantage if we take into account the fact that international environmental law is defined based on the objective criterion of the regulation ${ }^{50}$. From among the doctrinal definitions that have emerged, given the role of the Stockholm Conference for developments in the operation of international environmental law and, within it, international climate law, it is worth referring to the definition created by Secretary-General U'Thant in the 1969 report Man and His Environment. According to the definition contained therein, the environment is defined as the physical and biological surrounding of a human being, regardless of whether it is a natural or man-made environment.

The concept of climate change is equally important to the issue of liability for damages caused by climate change. It has been defined in the United Nations Framework Convention on Climate Change as changes in the climate caused directly or indirectly by human activity that alters the composition of the earth's atmosphere and that are distinguished from the natural variability of the climate observed over comparable periods of time $^{51}$. The adverse effects of climate change, which for purposes of considering the liability for damages of states must be equated with damage, are defined in the Convention as changes in the physical environment or biota caused by climate change that have a significant adverse effect on the composition, resilience or productivity of natural, controlled ecosys-

48 Maria Magdalena Kenig-Witkowska, Międzynarodowe prawo środowiska, Wybór i wprowadzenie Maria Magdalena Kenig-Witkowska (Warsaw: Wolters Kluwer, 2009), 16.

49 Karen Scott, "International environmental governance: managing fragmentation through institutional connection," Melbourne Journal of International Law 12 (2011): 3.

50 Maciej Nyka, Instrumenty ograniczania wptywu handlu a środowisko. Studium z prawa międzynarodowego (Warsaw: Difin, 2018), 39.

51 Art. 1 pt. 3. 
tems or on the functioning of socioeconomic systems or on human health and welfare ${ }^{52}$. The definitions cited above indicate the broad spectrum of potential damages that may be considered for international climate compensation liability. They also give some idea of the size of potential compensation claims in this area.

\section{THE PROBLEM OF ESTABLISHING A CAUSAL RELATIONSHIP AND ATTRIBUTING THE OCCURRENCE OF CLIMATE DAMAGE}

An issue often raised in analyses relating to the feasibility of climate damage liability is that of causation. This is, in fact, a key issue, the resolution of which seems to be at least as important as the possibility of attributing liability. At the beginning of the consideration of the causal link between the behavior of states and the occurrence of damage, it should be emphasized that models and reports relating to the risks associated with climate change and the types of activity causing these changes were already known in general terms in the 1980s. The Intergovernmental Panel on Climate Change, established by the UN General Assembly in $1988^{53}$ has so far prepared five summary reports, which constitute a compendium of scientific knowledge about the causes and effects of climate change.

Another problem and challenge may be that when basing claims on general international law standards of liability, the ability to attribute specific damage to a particular state action is extremely difficult ${ }^{54}$. Similarly, the distinction between damage caused by natural phenomena and damage caused in fact by the same phenomena, but of greater intensity, frequency or scale, resulting from anthropogenic emissions is extremely $\operatorname{hard}^{55}$. This is due to the presence of synergies in the context of emissions and the nonlinear impact of these emissions on the occurrence of

52 Art. 1 pt. 1.

53 Protection of global climate for present and future generations of mankind United Nations General Assembly Resolution of $6^{\text {th }}$ December 1988 A/RES/43/53.

54 Kenig-Witkowska, Międzynarodowe prawo środowiska, Wybór i wprowadzenie Maria Magdalena Kenig-Witkowska, 139.

55 Mayer, "Climate Change Reparations and the Law," 204. 
adverse effects of climate change ${ }^{56}$. Therefore, it may become a problem to demonstrate the direct and specific impact of the state's actions or omissions on climate change, especially on the resulting damage. It must be remembered that Art. 31 (2) of the articles on the liability of states for acts contrary to international law, and in fact the commentary to this article indicates the exclusion of damages in which the cause of the occurrence is too distant and the causal link is not direct ${ }^{57}$. On the other hand, the jurisprudence of international courts seems to indicate something quite different. In the Naulilaa case, the Arbitration Panel indicated that even the relatively distant negative consequences of an attack on Portugal's colonies could be foreseen ${ }^{58}$. In the Corfu judgment, the Tribunal considered that the probability of occurrence of damage ${ }^{59}$ related to the lack of response from the Albanian authorities, was sufficient.

In the context of problems with indicating a causal relationship, it is also worth pointing to the specificity of cases settled on the basis of the norms of international environmental law. In the case of Southern Bluefin Tuna. The International Tribunal for the Law of the Sea made a very interesting use of the precautionary principle. Its use in the assessment of the dispute between Japan and New Zealand and Australia resulted in the lack of the need to prove beyond any doubt the existence of a link between actions and possible damage, in particular when we are dealing with a cause-and-effect relationship which is complicated ${ }^{60}$.

\section{INTERNATIONAL LEGAL CHALLENGES TO ESTIMATING CLIMATE DAMAGES}

An extremely interesting issue related to the realization of the compensation liability of states for climate damage is the issue of the method of es-

56 Kenig-Witkowska, Międzynarodowe prawo środowiska, Wybór i wprowadzenie Maria Magdalena Kenig-Witkowska, 139.

57 art. 31, pt. 10 Draft articles on Responsibility of States for Internationally Wrongful Acts, with commentaries.

58 The Naulilaa Case 2 R. Int'l Arb. Awards 1011 (1949).

59 Corfu Channel, United Kingdom v Albania, Judgment, Merits, [1949] ICJ Rep 4.

60 ITLOS Case No 3 (Official Case No) (1999) 38 ILM 1624. 
timating the amount of claims. The doctrine rightly argues that the issue of measurability of damages caused to the environment as a result of climate change is one of the more interesting problems related to compensation of such damages, and their legal assessment depends on the findings of natural and economic sciences in terms of the effects of climate change on the environment of the Earth ${ }^{61}$. Past practice of international courts and tribunals indicates that most environmental damage valuation processes involve small and non-catastrophic changes in the condition of individual environmental elements ${ }^{62}$. Damages on a global scale, and climate damage can be treated as such, are so far beyond the jurisdiction of these courts.

Reflection on the choice of an international court indicates that the most intuitive one would be the International Court of Justice operating within the structures of the United Nations. The International Court of Justice has rarely ruled on issues relating to the assessment of damages. Among the three cases in which the Court addressed this issue, only one referred to the problem of compensation for environmental damage. That case was decided in early 2018 and seems to point to a plausible way to estimate damages that could be applied to climate damage. In Costa Rica vs Nicaragua ${ }^{63}$, concerning compensation for unlawful interference into water courses, the International Court of Justice upheld the obligation to redress the damage in the form of compensation resulting from the previous jurisprudence. Already in the above-mentioned case of the Factory in Chorzów, the Permanent Court of International Justice pointed to the fact that compensation should remove all effects of illegal activity ${ }^{64}$. The principle of full compensation for environmental damage was identified by the ICJ in the Pulp Mills case, where the Court also recognized the possibility of remedying the harm by paying compensation ${ }^{65}$. On the other hand, in the same judgment, the Court stipulated that compensation in such cases should not be punitive. The principle of full compensation for damage in the context of climatic damage may be subject to important

61 Ciechanowicz-McLean, Prawo ochrony klimatu, 168.

62 Ciechanowicz-McLean, Prawo ochrony klimatu, 167.

63 Certain Activities Carried Out by Nicaragua in the Border Area (Costa Rica v. Nicaragua), Compensation, Judgment, I.C.J. Rep. 2018, p. 15.

641928 P.C.I.J Series A No 17 p. 47.

65 Pulp Mills on the River Uruguay ICJ Rep. 2010 (I) p. 103 i 104 par. 273. 
limitations, which may be justified by the specific nature and extent of the climatic damage, but also by the characteristics of the state towards which the obligation to compensate has been established ${ }^{66}$.

Moving within the boundary conditions cited above, the Court, in deciding on the issue of compensation in Costa Rica vs. Nicaragua, considered as compensable the limitations or loss of the ability of an ecosystem to provide ecosystem services ${ }^{67}$. In the doctrine, ecosystem services are referred to as the circulation of energy and substances in the environment observed by researchers engaged in the analysis of the functioning of ecosystems, and the very existence of the ecosystem provides certain benefits to humans, which are called ecosystem services ${ }^{68}$. The doctrine contains many different definitions of ecosystem services. One of the first was formulated in 1997 by Constanza et al., stating that environmental goods and services consist of flows of matter, energy, and information from natural resources that, together with man-made goods and services, contribute to human well-being ${ }^{69}$. In the case under review, the estimation of environmental damage by this method was advocated by Costa Rica ${ }^{70}$.

The Court, in valuing the ecosystem goods and services lost as a result of Nicaragua's unlawful actions, rejected Costa Rica's valuation, which was based on estimating the monetary value of particular categories of environmental goods and services over the time scale necessary to restore them. These calculations made even under the method adopted by Costa Rica seemed overestimated. Instead, it focused on the value of the services provided by the ecosystem as a whole and the difference in their value resulting from the environmental damage caused by Nic-

66 Mayer, "Climate Change Reparations and the Law," 203.

67 Certain Activities Carried Out by Nicaragua in the Border Area (Costa Rica v. Nicaragua), Compensation, Judgment, I.C.J. Rep. 2018, Par. 42.

${ }_{68}$ Robert Costanza, Ralph d'Arge, Rudolf de Groot, Stephen Farber, Monica Grasso, Bruce Hannon, Karin Limburg, Shahid Naeem, Robert V. O’Neill, Jose Paruelo, Robert G. Raskin, Paul Sutton, and Marjan van den Belt, "The Value of the World's Ecosystem Services and Natural Capital,” Nature 387 (1997): 255.

69 Costanza, d'Arge, de Groot, and et. al., "The Value of the World's Ecosystem," 256.

70 Certain Activities Carried Out by Nicaragua in the Border Area (Costa Rica v. Nicaragua), Compensation, Judgment, I.C.J. Rep. 2018, Par. 46, par. 47. 
aragua's actions ${ }^{71}$. The Court first identified which ecosystem services were likely to be impaired as a result of the unlawful activity and then assessed the damage separately for each of them. Moreover, the Court took into account when estimating the harm to the availability of ecosystem services not only that these services are likely to be restored after a certain period of time, but also that the restoration of the availability of these services will be gradual and so the damage will diminish over time. The Court also pointed out that the damage will have a different temporal dimension for each of the ecosystem service categories under consideration $^{72}$. The issue of long-term but diminishing over time effects on ecosystem services was also raised in the context of $\mathrm{CO}_{2}$ sequestration services. Here, the Court disagreed with Nicaragua's suggestion that the damage was one-off and also took into account the multi-year time perspective of the assessed damage.

In valuing the damage to the availability of particular ecosystem services, the Court also took into account the fact that part of the area negatively impacted by Nicaragua was the so-called Ramsar Site, i.e. a protected area included in the list of protected areas of the Ramsar Convention of Wetlands. In the Court's view, this was relevant in valuing the damage to services that sustain biodiversity ${ }^{73}$. In summarizing the estimated damages, the Court referred to the Trail Smelter ruling already mentioned in this article, and the Ahmadu Sadio Dallo case ${ }^{74}$, stating that the impossibility of an accurate estimate of the damage should not be an obstacle to its compensation, and that in such a situation, the decision may be based on the Court's equitable estimates ${ }^{75}$.

71 Certain Activities Carried Out by Nicaragua in the Border Area (Costa Rica v. Nicaragua), Compensation, Judgment, par. 78.

72 Certain Activities Carried Out by Nicaragua in the Border Area (Costa Rica v. Nicaragua), Compensation, Judgment, par. 82.

73 Certain Activities Carried Out by Nicaragua in the Border Area (Costa Rica v. Nicaragua), Compensation, Judgment, par. 80.

74 Ahmadou Sadio Diallo, Guinea v Democratic Republic of the Congo, Judgment, Preliminary Objections, ICJ GL No 103, ICGJ 52 (ICJ 2007).

75 Ahmadou Sadio Diallo, Guinea v Democratic Republic of the Congo, Judgment, Preliminary Objections par. 86. 


\section{CONCLUSIONS}

The considerations presented above allow the formulation of several conclusions. International climate law, despite its dynamic development and certain aspirations in this respect, has not yet developed a specific system within which States' liability for damages could be exercised. The Warsaw International Mechanism for Loss and Damage is an instrument for the implementation of broadly understood environmental justice, mainly in the intra-generational dimension, but it does not introduce mechanisms for the implementation of compensation liability of states. In the absence of specific mechanisms for the exercise of responsibility for climate damage, claims in this area will be implemented on the basis of mechanisms specific to general international law. The implementation of compensatory liability in relation to climate damage is achievable both under tort responsibility and under the regime of non-prohibited acts liability. In practice, however, this distinction introduced mainly by the ILA Working Group loses its relevance. The exercise of states' liability for damages in the area of climate protection faces a whole range of difficulties. They are inherent in the whole problem of liability for environmental damage. The mechanisms of indemnity liability of states for environmental damage occur both within specific subsystems (nuclear damage, space damage, etc.) and outside them. Difficulties related to the specificity of the implementation of compensatory liability for climate damage appear to be surmountable in light of recent decisions of the International Court of Justice in environmental cases. They indicate the possible directions of argumentation in the event of a dispute concerning the state's liability for climate damage. Concepts based on the acquis of the Convention on Biological Diversity, especially the concept of ecosystem services, are likely to play a leading role in such claims.

\section{REFERENCES}

Birnie, Patricia, and Alan Boyle. International Law \& the Environment. $2^{\text {nd }}$ ed. Oxford: Oxford University Press, 2002.

Brunnée, Jutta, and Stephen J. Toope. "Climate Change: Building a global legal regime." In Legitimacy and Legality in International Law. An International ac- 
count, edited by Jutta Brunnée and Stephen Toope, 126-219. Cambridge: Cambridge University Press, 2010.

Ciechanowicz-McLean, Janina. "Prawno-ekonomiczne aspekty zmian klimatu." In Zmiany klimatu a spoteczeństwo, edited by Leszek Karski, and Irena Grochowska, 341-348. Warsaw: C.H. Beck, 2010.

Ciechanowicz-McLean, Janina. Prawo ochrony klimatu. Warsaw: Powszechne Wydawnictwo Prawnicze, 2016.

Ciechanowicz-McLean, Janina, and Maciej Nyka. Environmental Law. Gdańsk, Warsaw: Wolters Kluwer, 2016.

Costanza, Robert, Ralph d'Arge, Rudolf de Groot, Stephen Farber, Monica Grasso, Bruce Hannon, Karin Limburg, Shahid Naeem, Robert V. O’Neill, Jose Paruelo, Robert G. Raskin, Paul Sutton, and Marjan van den Belt. "The Value of the World's Ecosystem Services and Natural Capital.” Nature 387 (1997): 253-260.

Crawford, James, and Simon Olleson. "The Nature and Forms of International Responsibility." In International Law, edited by Malcolm D. Evans, 441-471. New York: Oxford University Press, 2003.

Czapliński, Władysław. Podstawowe zagadnienia prawa międzynarodowego. Zarys wyktadu. Warsaw: Wydawnictwo Uniwersytetu Warszawskiego, 2009.

Czech, Ewa. Szkoda w obszarze środowiska i wina, jako determinanty odpowiedzialności administracyjnej za szkodę. Białystok: Trans Humana, 2008.

Fitzmaurice, Małgosia, and Catherine Redgwell. "Environmental Non-Compliance Procedures and International Law." Netherlands Yearbook of International Law 31 (2000): 35-65.

Higgins, Rosalyn. Problems and Process: International Law and How We Use It. Oxford: Clarendon Press, 2003.

Kenig-Witkowska, Maria Magdalena. Międzynarodowe prawo środowiska. Wybrane zagadnienia systemowe. Warsaw: Wolters Kluwer, 2011.

Kenig-Witkowska, Maria Magdalena. Międzynarodowe prawo środowiska, Wybór i wprowadzenie Maria Magdalena Kenig-Witkowska. Warsaw: Wolters Kluwer, 2009.

King, David A. "Climate Change Science: Adapt, Mitigate or Ignore?." Science 303, no. 5655 (2004): 176-177.

Kocot, Kazimierz. Prawnomiędzynarodowe zasady sozologii. Warsaw-Wrocław: Polskie Wydawnictwa Naukowe, 1977.

Mace, Mary Jane, and Roda Verheyen. "Loss, Damage and Responsibility after COP21: All Options Open for the Paris Agreement." Review of European Community \& International Environmental Law 25, no. 2 (2016): 197-214.

Mayer, Benoit. "Climate Change Reparations and the Law and Practice of State Responsibility." Asian Journal of International Law 7 (2017): 185-216. 
Nyka, Maciej. "Trade related instruments of promotion of human right to the environment in international climate law." In Právo na životné prostredie a nastroje jeho presadzovania, edited by Soňa Košičiarová, 173-185. Trnava: Trnavská univerzita. Právnická fakulta, 2016.

Nyka, Maciej. Instrumenty ograniczania wptywu handlu a środowisko. Studium z prawa międzynarodowego. Warsaw: Difin, 2018.

Scott, Karen. "International environmental governance: managing fragmentation through institutional connection." Melbourne Journal of International Law 12 (2011): 177-216.

Similinger, Florentina, and Benoit Mayer. "Legal Responses to Climate Change Induced Loss and Damage." In Loss and Damage from Climate Change Concepts, Methods and Policy Options, edited by Reinchard Mechler, Laurens M. Bouwer, Thomas Schinko, Swenja Surminski, and JoAnne Linnerooth-Bayern, 179-203. Cham: SpringerOpen, 2019.

Simma, Bruno, and Dirk Pulkowski. "Of Planets and the Universe: Self Contained Regimes in International Law." European Journal of International Law 17, no. 3 (2006): 483-529.

Vicun, Francisco Orrego. "Institut de Droit International - Resolution on Responsibility and Liability: Responsibility and liability for Environmental Damage under International Law: Issues and Trends." Georgetown International Environmental Law Review 10 (1998): 279-308.

Voigt, Christina. "State Responsibility for Climate Change Damages." Nordic Journal of International Law 77 (2008): 1-22.

Zahar, Alexander. "Methological issues in climate law." Climate Law 5, no. 1 (2015): 25-34.

Zbaraszewska, Anna. "Prawnomiędzynarodowa odpowiedzialność za szkody transgraniczne w środowisku - problem prewencji." Ruch Prawniczy, Ekonomiczny i Socjologiczny 70, no. 2 (2008): 109-123. 